\title{
Predation on Tropidurus hispidus (Squamata: Tropiduridae) by Lasiodora klugi (Aranea: Theraphosidae) in the semiarid caatinga region of northeastern Brazil
}

\author{
Washington Luiz Silva Vieira ${ }^{1,3}$, Maria Betânia Ribeiro Gonçalves ${ }^{2}$ \& Rômulo Pantoja Nóbrega ${ }^{1}$ \\ ${ }^{1}$ Laboratório de Ecofisiologia Animal, Departamento de Sistemática e Ecologia, \\ Universidade Federal da Paraíba - UFPB, CEP 58059-970, João Pessoa, PB, Brasil \\ ${ }^{2}$ Departamento de Biologia, Universidade Estadual da Paraíba - UEPB, Avenida das Baraúnas, \\ CEP 58109-753, Campina Grande, PB, Brasil \\ ${ }^{3}$ Corresponding author: Washington Luiz Silva Vieira, e-mail: wlsvieira@yahoo.com.br
}

VIEIRA, W.L.S., GONÇALVES, M.B.R. \& NÓGREGA, R.P. Predation on Tropidurus hispidus (Squamata: Tropiduridae) by Lasiodora klugi (Aranea: Theraphosidae) in the semiarid caatinga region of northeastern Brazil. Biota Neotrop. 12(4): http://www.biotaneotropica.org.br/v12n4/en/abstract?shortcommunication+bn02112042012

Abstract: A predation event on Tropidurus hispidus (Tropiduridae) by the crab spider Lasiodora klugi (Theraphosidae) was observed in an arboreal caatinga area in northeastern Brazil. Arthropods are potential predators of small vertebrates and researchers have reported predation events involving spiders and herpetofauna in Neotropical regions. As such, the present short communication is the second case of predation of spiders on Tropidurus lizards in Brazil, and the first for the semiarid caatinga, reinforcing the argument that large spiders have relevant roles as predators of these animals.

Keywords: natural history, prey-predator relationships, Lacertilia, Mygalomorphae, semiarid environment.

VIEIRA, W.L.S., GONÇALVES, M.B.R. \& NÓGREGA, R.P. Predação sobre Tropidurus hispidus (Squamata: Tropiduridae) por Lasiodora klugi (Aranea: Theraphosidae) na região de caatinga semiárida do nordeste do Brasil. Biota Neotrop. 12(4): http://www.biotaneotropica.org.br/v12n4/pt/abstract?shortcommunication+bn02112042012

Resumo: Um evento de predação sobre Tropidurus hispidus (Tropiduridae) pela aranha caranguejeira Lasiodora klugi (Theraphosidae) foi observado em área de caatinga arbórea no nordeste do Brasil. Artrópodes são potenciais predadores de pequenos vertebrados e pesquisadores têm relatado eventos de predação envolvendo aranhas e herpetofauna em regiões neotropicais. Portanto, a presente comunicação breve é o segundo caso de predação de aranha sobre lagartos do gênero Tropidurus no Brasil e o primeiro para as caatingas semiáridas, reforçando a argumentação de que grandes aranhas possuem um papel relevante como predadores desses animais.

Palavras-chave: história natural, relação presa-predador, Lacertilia, Mygalomorphae, ambiente semiárido. 


\section{Introduction}

Predator-prey relationships are one of the main ecological factors structuring vertebrate and invertebrate assemblages (Sandidge 2004, Vitt \& Caldwell 2009). These important interactions influence utilization strategies of food resources among different species groups (Toft 1985) and can result in non-random patterns of interspecific relationships between different types of predators (Gotelli \& Entsminger 2001).

Vertebrates are the main predators of arthropods, and insects and spiders are the most representative food items in the diet of a large numbers of lizard species (Vitt \& Pianka 2005). However, arthropods, especially spiders, are likewise potential predators of small vertebrates (McCormick \& Polis 1982). Numerous researchers have reported predation events involving spiders and herpetofauna in Neotropical regions (e.g. Raven 1990, Prado \& Borgo 2003, Menin et al. 2005, Pombal Junior 2007, Barbo et al. 2009, Maffei et al. 2010, Bocchiglieri \& Mendonça 2010, Maffei et al. 2010, Sousa \& Freire 2010a, Moura \& Azevedo 2011, Diniz 2011).

Within this context, it must be noted that Armas \& Alayón (1987) reported individuals of Argiope trifasciata (Forsskål, 1775) (Araneidae) as predators of the arboreal lizards Anolis porcatus Gray, 1840 and A. sagrei Duméril \& Bibron 1837 (Polychrotidae); Schwammer \& Baurecht (1988) and Blondheim \& Werner (1989) reported predation events of Latrodectus spiders (Theridiidae) on Podarcis melisellensis (Braun, 1877) and Mesalina guttulata (Lichtenstein, 1823) (Lacertidae); Bauer (1990) prepared a review of spiders as predators of lizards of the Gekkonidae family; Armas (2000) published a survey of arachnids as predators of frogs and lizards in the Greater Antilles; Maffei et al. (2010) reported predation events of the wolf-spider Lycosa erythrognatha Lucas, 1836 (Lycosidae) on gymnophthalmid species in the Cerrado (savanna) of central Brazil; and Diniz (2011) documented the predation of Hemidactylus mabouia (Moreau De Jonnès, 1818) (Gekkonidae) by the giant orb-weaver spider Nephilengys cruentata Fabricius, 1775 (Nephilidae). Considering the importance of spiders as predators of lizards, this short communication reports the first recorded event of Lasiodora klugi (Koch, 1848) (Theraphosidae) preying on Tropidurus hispidus (Spix, 1825) (Tropiduridae) in the semiarid region of northeastern Brazil (Figure 1).

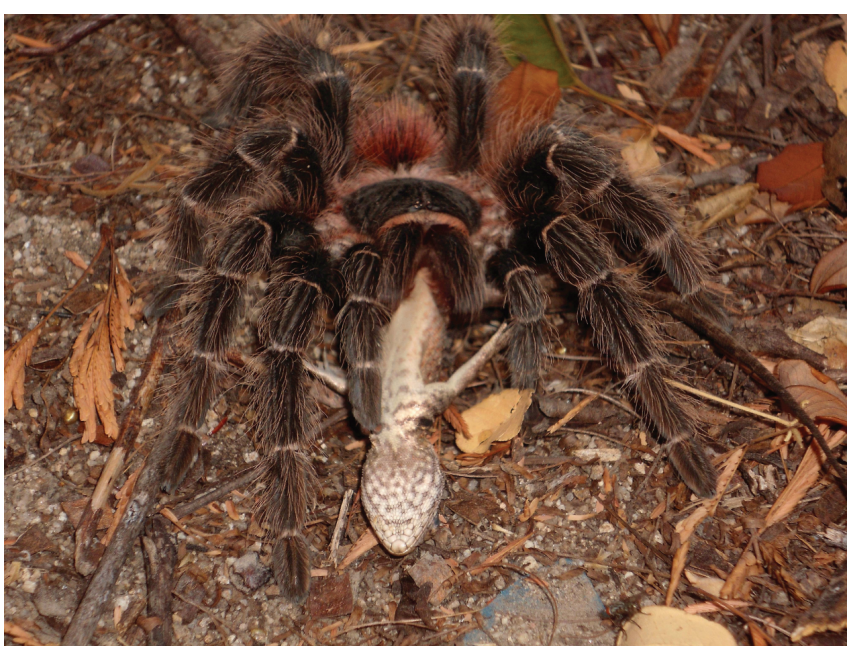

Figure 1. Predation of Tropidurus hispidus by the Theraphosid spider Lasiodora kluge (50 mm/cephalothorax + abdomen length), observed in an area of arboreal caatinga in the Almas Farm RPPN, in the municipality of São José dos Cordeiros, Paraíba, northeastern Brazil. Photograph: Washington L.S.Vieira.

\section{Materials and Methods}

This predation event was observed during fieldwork focusing on the ecology of reptiles and amphibians within the Long-Term Ecological Research Program (PELD - Caatinga: Estrutura e Funcionamento) and the Universal - Edital MCT/CNPQ No 14/2011 research project in an area of arboreal caatinga at the Fazenda Almas. This area is included in the Natural Private Reserve (Reserva Particular do Patrimônio Natural-RPPN) and covers an area of 5500 ha in the municipality of São José dos Cordeiros, state of Paraíba, in northeastern Brazil ( $7^{\circ} 28^{\prime} 15^{\prime \prime} \mathrm{S}$ and $\left.36^{\circ} 52^{\prime} 51^{\prime \prime} \mathrm{W}\right)$.

\section{Results and Discussion}

On April 26, 2012 (8:00 AM) an adult female specimen of Lasiodora klugi (Koch, 1848) was observed feeding on an adult female specimen of Tropidurus hispidus (Spix, 1825) amidst the leaf litter of the dry forest floor (Figure 1). As we approached the animals, the spider began to retreat while carrying the lizard under its body (holding it with its chelicerae and pedipalps) for a distance of approximately $10 \mathrm{~m}$, with short pauses, until finally reaching and entering a small hole in the ground; the entire distance was covered in approximately 10 minutes. Since the spider entered a hole, it was not possible to collect it or its prey for inclusion in a scientific collection. However, photographs taken of this predation event were incorporated into the image and video bank of the Laboratório de Ecofisiologia Animal at the Universidade Federal da Paraíba, Paraíba, Brazil.

Tropidurus hispidus is a small lizard, approximately $140 \mathrm{~mm}$ long (SVL), with diurnal habits and a wide distribution range through northeastern South America - predominantly in the caatinga biome of northeastern Brazil, in open areas north of the Amazon River, and in the central Amazon region near the city of Manaus (where it was apparently introduced) (Rodrigues 1987, Vitt et al. 2008). Lasiodora klugi is a Theraphosid spider that reaches $50 \mathrm{~mm}$ (cephalothorax + abdomen length) (S. Lucas, pers. comm.). This species has an ample geographical distribution, with records in both the caatinga and cerrado (Brazilian savanna) biomes (Bertani 2001).

Individuals of both T. hispidus and L. klugi are commonly observed co-habiting rock outcrops and crevices and areas with hyperxerophilic vegetation (W. Vieira, pers. obs.) - which suggests that predation of these lizards by Theraphosid spider may be quite common in these environments. Arachnids are some of the principal predators of small animals that inhabit the forest floor in the Neotropical region, and predation of terrestrial vertebrates such as frogs and lizards is probably quite common (Armas 2000, Menin et al. 2005, Barbo et al. 2009). Predation events by arthropods on vertebrate assemblages are quite difficult to record, however, and the observer must be continually attentive while exploring microhabitats where these predators are found to be able to observe them during the short moments when they are capturing and/or devouring their prey (Pombal Junior 2007).

Bocchiglieri \& Mendonça (2010) reported a wolf spider (Lycosa erythrognatha) feeding on an adult Tropidurus oreadicus Rodrigues, 1987 in a pitfall trap in southeastern Brazil - which was the first report of predation on a lizard of this genus by a spider. As such, the present report is the second case of predation of spiders on Tropidurus lizards in Brazil, and the first for the semiarid caatinga - reinforcing the argument that spiders of the families Theraphosidae and Lycosidae have important roles as predators of these animals.

The few publications that have examined predator-prey relationships between spiders (and other arthropods) and Brazilian lizards in seasonal environments have recorded events involving Lycosa erythrognatha preying on Micrablepharus atticolus 
Rodrigues, 1996 in an area of Cerrado (Brazilian savanna vegetation) in central Brazil (Maffei et al. 2010), a non-identified theraphosid spider preying on Micrablepharus maximiliani (Reinhardt \& Lütken, 1862) (Sousa \& Freire 2010a) in a restinga (coastal) area, and a large ant of the species Dinoponera quadriceps Santschi, 1921 preying on the small lizard Coleodactylus natalensis Freire, 1999 (Sousa \& Freire 2010b) in a remnant area of semi-deciduous Atlantic Forest (the latter two in northeastern Brazil); Ribeiro et al. (2011) also observed predation events on Hemidactylus brasilianus (Amaral, 1935) and Cnemidophorus ocellifer (Spix, 1825) by D. quadriceps in an area of caatinga.

Within this context, this short communication increases the knowledge of the trophic interactions that occur between arthropods and lizards in the semiarid caatinga regions of northeastern Brazil, which suggest that predation of these lizards by Theraphosid spider may be quite common in these environments.

\section{Acknowledgements}

The authors would like to thank Eunice Braz (in memoriam) and the current administrator of Arimatéia Braz for allowing us to undertake this study in the Almas Farm and RPPN; Roberto Lima for his support and collaboration during the field work; PELD/CNPq and MCTI/CNPq No 14/2011 for their financial support of research activities in the study area; the Instituto Brasileiro do Meio Ambiente e dos Recursos Naturais Renováveis (IBAMA/RAN) for issuing the collection permit (Number 14105-2); Sylvia M. Lucas and Antônio D. Brescovit (Laboratório de Artrópodes/Instituto Butantan, São Paulo, SP, Brazil) for her help in identifying the species from photographic records; to editor and anonymous referees by valuable suggestions on the manuscript.

\section{References}

ARMAS, L.F. 2000. Frogs and lizards as prey of some Greater Antillean arachnids. Revta. Iber. Aracnol. 3:87-88.

ARMAS, L.F. \& ALAYÓN, G.G. 1987. Observaciones sobre la ecología trófica de una población de Argiope trifasciata (Araneae: Araneidae) en el Sur de La Habana. Poeyana 344:1-18.

BAUER, A.M. 1990. Gekkonid lizards as prey of invertebrates and predators of vertebrates. Herpetol. Rev. 21:83-87.

BARBO, F.E., RODRIGUES, M.G, COUTO, F.M. \& SAWAYA, R.J. 2009. Predation on Leptodactylus marmoratus (Anura: Leptodactylidae) by the spider Ctenus medius (Araneae: Ctenidae) in the Atlantic Forest, southeast Brazil. Herpetol. Notes. 2:99-100.

BERTANI, R. 2001. Revision, cladistics analysis, and zoogeography of Vitalus, Nhandu, and Proshapalopus; with notes on other Theraphosine genera (Araneae, Theraphosidae). Arq. Zool. 36(3):265-356.

BLONDHEIM, S. \& WERNER, Y.L. 1989. Lizard predation by the widow spiders Latrodectus pallidus and L. revivensis (Theridiidae). Brit. Herp. Soc. Bull. 30:26-27.

BOCCHIGLIERI, A. \& MENDONÇA, A.F. 2010. Tropidurus oreadicus (neotropical ground lizard). Predation. Herpetol. Rev. 41:231-231.
DINIZ, S. 2011. Predation and feeding on the tropical house gecko Hemidactylus mabouia (Squamata: Gekkonidae) by the giant orbweaver spider Nephilengys cruentata (Araneae: Nephilidae). Herpetol. Notes. 4:357-358.

GOTELLI, N.J. \& ENTSMINGER, G.L. 2001. EcoSim: Null models software for ecology. Acquired Intelligence Inc. and Kesey-Bear, Burlington, Vermont.

MAFFEI, F., UBAID, F.K. \& JIM, J. 2010. Predation of herps by spiders (Araneae) in the Brazilian Cerrado. Herpetol. Notes. 3:167-170.

McCORMICK, S. \& POLIS, G.A. 1982. Invertebrates that preys on vertebrates. Biol. Rev. 57:29-58. http://dx.doi.org/10.1111/j.1469185X.1982.tb00363.X

MENIN, M., RODRIGUES, D.J. \& AZEVEDO, C.S. 2005. Predation on amphibians by spiders (Arachnida, Araneae) in the Neotropical region. Phyllomedusa 4(1):39-47.

MOURA, M.R. \& AZEVEDO, L.P. 2011. Observation of predation of the giant fishing spider Ancylometes rufus (Walckenaer, 1837) (Araneae, Ctenidae) on Dendropsophus melanargyreus Cope, 1877 (Anura, Hylidae). Biota Neotropica 11(4): http//www.biotaneptropica.org.br/ v11n4/em/abstract?short-comunication+bn00211042011 http://dx.doi. org/10.1590/S1676-06032011000400028

POMBAL JUNIOR, J.P. 2007. Notas sobre predação em uma taxocenose de anuros no sudeste do Brasil. Rev. Bras. Zool. 24(3):841-843. http:// dx.doi.org/10.1590/S0101-81752007000300034

PRADO, G.M. \& BORGO, J.H. 2003. Scinax alterus (NCN). Predation. Herpetol. Rev. 34(3):238-239.

RAVEN, R.J. 1990. Spider predators of reptiles and amphibia. Mem. Queens1. Mus. 29:448.

RIBEIRO, L.B., GOGLIATH, M. \& FREIRE, E.M.X. 2011. Hemidactylus brasilianus (Amaral's Brazilian Gecko) and Cnemidophorus ocellifer (Spix's Whiptail). Predation. Herpetol. Bull. 117:31-32.

RODRIGUES, M.T. 1987. Sistemática, ecologia e zoogeografia dos Tropidurus do grupo Torquatus ao sul do Rio Amazonas (Sauria, Iguanidae). Arq. Zool. 31(3):105-230.

SANDIDGE, J. 2004. Predation by Cosmopolitan Spiders Upon the Medically Significant Pest Species Loxosceles reclusa (Araneae: Sicariidae): Limited Possibilities for Biological Control. J. Econ. Entomol. 97(2):230-234. http://dx.doi.org/10.1603/0022-0493-97.2.230

SCHWAMMER, H. \& BAURECHT, D. 1988. DerKarstläufer, Podarcis melisellensis fiumana (Werner, 1891), als Beute der Europäischen Schwarzen Witwe, Latrodectus mactans tredecimguttatus (Rossi, 1970). Herpetozoa 1(2):73-76.

SOUSA, P.A.G. \& FREIRE, E.M.X. 2010a. Micrablepharus maximiliani (Blue-tailed Lizard). Predation. Herpetol. Rev. 41:82-83.

SOUSA, P.A.G. \& FREIRE, E.M.X. 2010b. Coleodactylus natalensis (NCN). Predation. Herpetol. Rev. 41:218-219.

VITT, L.J., MAGNUSSON, W.E., AVILA-PIRES, T.C.S. \& LIMA, A.P. 2008. Guia de lagartos da Reserva Adolpho Ducke, Amazônia Central. Áttena Desing, Manaus.

VITT, J., \& PIANKA, E.R. 2005. Deep history impacts present-day ecology and biodiversity. PNAS 102(22):7877-7881. http://dx.doi.org/10.1073/ pnas. 0501104102

VITT, L.J. \& CALDWELL, J.P. 2009. Herpetology: An Introductory Biology of Amphibians and Reptiles. 3rd ed. Academic Press, 697p.

TOFT, C.A. 1985. Resource partitioning in amphibians and reptiles. Copeia (1):1-21. http://dx.doi.org/10.2307/1444785 